\title{
LEVEL OF SATISFACTION WITH SOCIO ECONOMIC PREFERENCES FOR NEIGHBOURHOOD QUALITY
}

\author{
Norainah Abdul Rahman1, Nor Eeda Ali2, Norhazlan Haron3, Kamariah Abdullah4 \\ 1,2,3,4 Universiti Teknologi MARA, Perak Branch, Malaysia. +6053742000 \\ Email: norai760@uitm.edu.my
}

\begin{abstract}
INFORMASI ARTIKEL
Abstract: This paper is continuation from pervious paper on neighbourhood quality. There are two variables used for socio economic background used are which are monthly income and home ownership. The key target of the study is assess the level of satisfaction of neighbourhood facilities and services with different socio economic background. Selfadministered questionnaire survey distributed at three neighbourhood area in Manjung District Perak Malaysia with the sample of 421 respondents. Basically the result shows that all neighbourhood facilities and services are moderate to less level of satisfaction by different socio economic background. Even though at moderate level below 4.00 scale, the result shows that the lower income gives better level of satisfaction (3.63) compared to the higher income a bit lower level of satisfaction (3.45). Nevertheless peoples who have different home ownership gives almost similar result with average moderate below 4.00 scale. People who stay at their own house scale at 3.53, who stay at rental house scale at 3.57 and other house scale ate 3.57. Based on the result the local authority the Manjung Municipal Council and related agencies must be take into account to upgrade and improve the neighbourhood facilities and services in their neighbourhood area. The feedbacks from the peoples are the best method to get the actual situation and exact facts.
\end{abstract}

Keywords: Level of Satisfaction, Socio Economic, Neighbourhood Facilities and Services, Neighbourhood Quality

\begin{abstract}
Abstrak: Makalah ini merupakan kelanjutan dari kertas sebelumnya tentang kualitas lingkungan. Ada dua variabel yang digunakan untuk latar belakang sosial ekonomi yang digunakan yaitu pendapatan bulanan dan kepemilikan rumah. Sasaran utama dari penelitian ini adalah menilai tingkat kepuasan fasilitas dan layanan lingkungan dengan latar belakang sosial ekonomi yang berbeda. Survei kuesioner yang dikelola sendiri didistribusikan di tiga area lingkungan di Manjung Distrik Perak Malaysia dengan sampel 421 responden. Pada dasarnya hasilnya menunjukkan bahwa semua fasilitas dan layanan lingkungan adalah tingkat kepuasan sedang sampai kurang oleh latar belakang sosial ekonomi yang berbeda. Meskipun pada tingkat moderat di bawah skala 4,00, hasilnya menunjukkan bahwa pendapatan yang lebih rendah memberikan tingkat kepuasan yang lebih baik $(3,63)$ dibandingkan dengan pendapatan yang lebih tinggi tingkat kepuasan yang rendah $(3,45)$. Namun demikian orang-orang yang memiliki kepemilikan rumah yang berbeda memberikan hasil yang hampir serupa dengan rata-rata sedang di bawah skala 4,00. Orang-orang yang tinggal di skala rumah mereka sendiri di 3,53, yang tinggal di skala rumah sewa di 3,57 dan skala rumah lainnya makan 3,57. Berdasarkan pada hasil otoritas lokal Dewan Kota Manjung dan lembaga terkait harus diperhitungkan untuk meningkatkan dan meningkatkan fasilitas dan layanan lingkungan di daerah lingkungan mereka. Umpan balik dari masyarakat adalah metode terbaik untuk mendapatkan situasi aktual dan fakta yang sebenarnya.
\end{abstract}

Kata Kunci: Tingkat Kepuasan, Sosial Ekonomi, Fasilitas dan Layanan Lingkungan, Kualitas Lingkungan

Article history:

Received; 2020-07-25

Revised; 2020-09-14

Accepted; 2020-09-28 


\section{INTRODUCTION}

Various studies have been used the level of satisfaction model in assessing the developments of currents condition. Many previous researchers used Maslow's hierarchy of needs theory as the basis in developing the level of satisfaction model research in the housing environment (Sulaiman \& Yahaya, 1987; Yi, 1985), in the residential environment (Galster \& Hesser, 1981; Niezabitowski, 1987) and in the neighbourhood environment (Connerly \& Marans, 1985; Lee \& Marans, 1980). The current studies have used the level satisfaction model to enrich the elements in terms of three main purposes. Firstly is for the evaluation and measurement, secondly is for the development of the index and framework and thirdly is for the clarification and verification of various situations and conditions in the housing and neighbourhood areas.

Evaluating the existing situation will later be used to improve future development (Ogu, 2002). Most studies wanted to identify the importance for their personal life and for their comfort (Chau, et al., 2006; Gbakeji \& Magnus, 2007). Some will be used to establish the most important factors affecting the level of satisfaction (Djebarni \& Al-Abed, 2000; Westaway, 2006). The development of index is for the residential environment system and the evaluation model, by using Geography Information System (GIS) calculations software for development and improvement of the neighbourhood areas (Ge \& Hokao, 2004).

Developing the index are important to promote the residents' perceived neighbourhood areas and may strengthened the spatial for environment and perceived restoration areas (Zhao, 2009). The multi elements neighbourhood need to be clarified and verified by using the level of satisfaction model because researchers can reconfirm the factors most influenced by the residents (Ge \& Hokao, 2006). Another advantage of clarifying and verifying in the level of satisfaction model is to test and validate the instruments of measurement and criteria (Yang, et al., 2002). The validation is for confirmatory factor analysis in producing quality fixed indexes of perceived quality indicators. Hence, they are well suited for use in research designs focusing on multiple elements measure of housing and neighbourhood areas (Bonaiuto, et al., 2003; Fornara, et al., 2010).

Many studies have mentioned that the different socio-economic background is very essential information in assessing the development. By using socio economic with many variables will gets more potential variances in the valuation of the same housing and neighbourhood condition by residents with different background (Tan, 2012). Aiello et al. (2010) put more attention on facilities, the satisfaction model still used the physical, social and economic model for the study in a neighbourhood area in Rome, Italy.

The economic attribute refers to the socio economics of the residents' backgrounds. Erkip (2010) concentrated on a high density neighbourhood in Ankara, Turkey. The conceptual framework in the satisfaction model was in the physical, social and economic model. The model included the socio demographics, socio economic and neighbourhood quality factors. The socio economic factors include the middle income, high income, homeownership, owners and tenants. While Sirgy and Cornwell (2002) used the conceptual model combination factor of physical, social and economic factors. The 
Jurnal Arsitektur dan Perencanaan (JUARA)

Hal. 160-172: ISSN Online: 2620-9896

Vol 3, No 2 (2020): September (Jurnal Arsitektur dan Perencanaan)

economic factors used as guidance for formulating the socio demographic and socio economic aspect of residents' background as independent variables.

\section{RESEARCH METHOD}

By using the same study area and method as in previous paper. There are 3 settlement centres in neighbourhood area selected in Manjung Perak Malaysia which are Seri Manjung, Sitiawan and Lumut while Seri Manjung is the town centre. Figure 1 and Figure 2 show the location of study area. Table 1 show the total population in the study area.

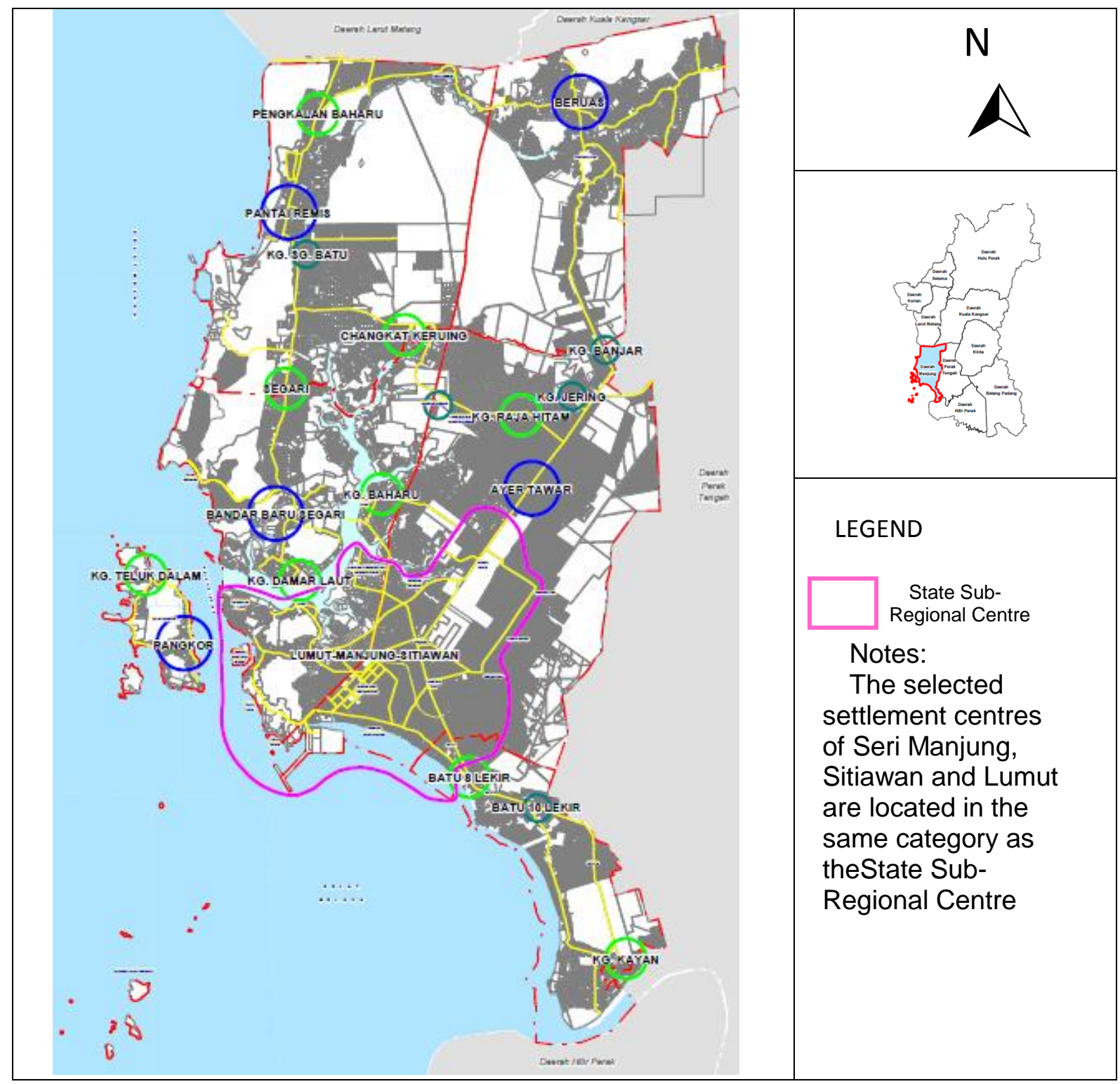

Figure 1: Three Settlement Centres Selected are Located in the Same Category in the State Sub-Regional Centre Note: Adopted from Manjung Municipal Council (2011) 


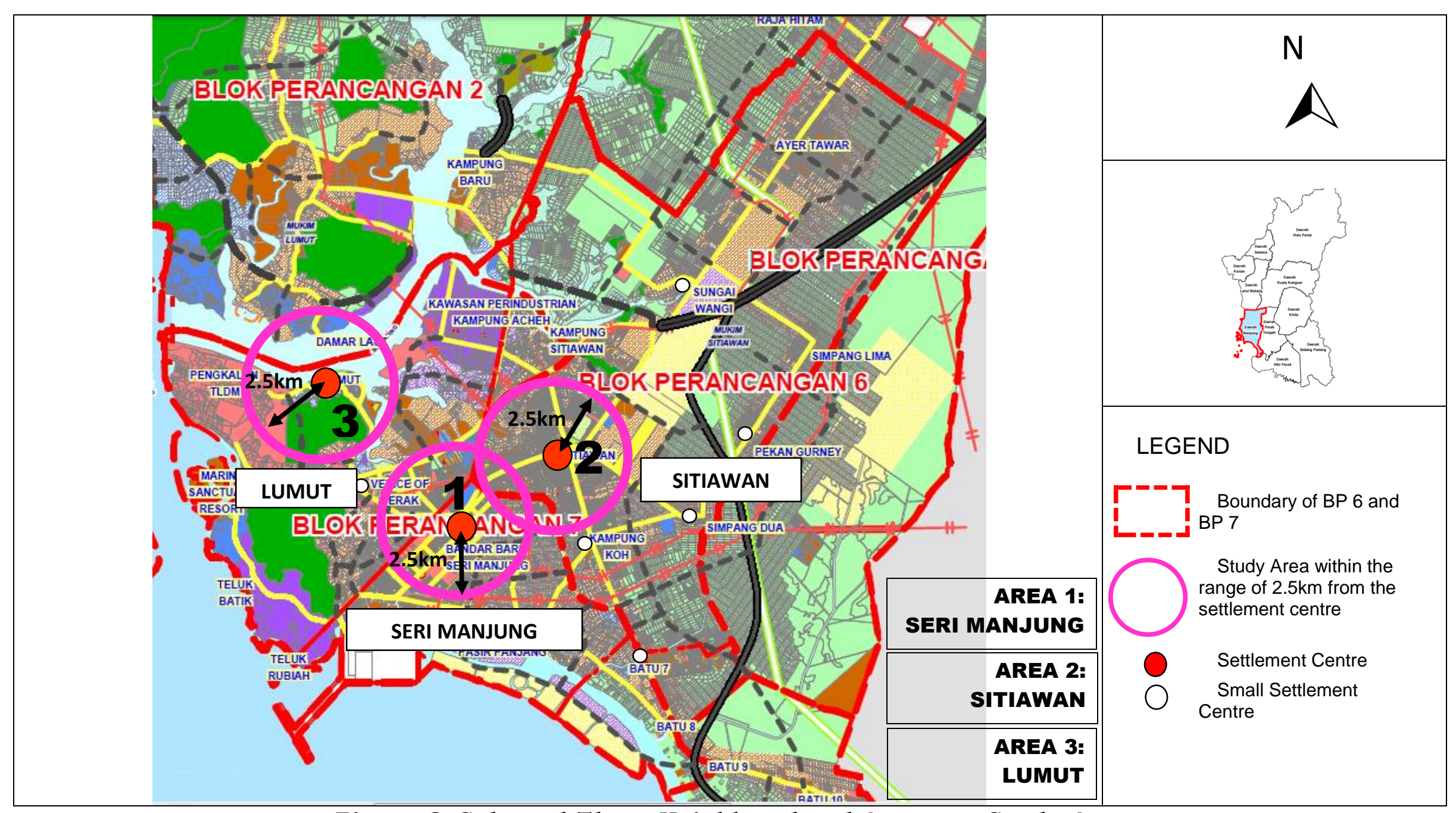

Figure 2: Selected Three Neighbourhood Area as a Study Area Note: Adapted from Manjung Municipal Council (2011) 
Vol 3, No 2 (2020): September (Jurnal Arsitektur dan Perencanaan)

\begin{tabular}{|c|c|c|c|}
\hline BP & $\begin{array}{l}\text { Settlement } \\
\text { Centre }\end{array}$ & Population 2010 & Neighbourhood Hierarchy \\
\hline \multirow[t]{2}{*}{7} & Seri Manjung & $42,058^{*}$ & $\begin{array}{c}2 \text { Neighbourhood Centres / } 6 \\
\text { Neighbourhoods / } 18 \text { Housing } \\
\text { Schemes }\end{array}$ \\
\hline & Lumut & $16,648^{*}$ & $\begin{array}{c}2 \text { Neighbourhoods / } 6 \text { Housing } \\
\text { Schemes }\end{array}$ \\
\hline 6 & Sitiawan & $32,176^{* *}$ & $\begin{array}{c}2 \text { Neighbourhood Centres / } 6 \\
\text { Neighbourhoods / } 18 \text { Housing } \\
\text { Schemes }\end{array}$ \\
\hline
\end{tabular}

Total

$\mathbf{9 0 , 8 8 2}$

Source: *Adopted from Manjung Municipal Council(2011) (1997a)

**Adopted from Manjung Municipal Council(2011) (1997b)

The socio economic background is the independent variables for the residents while the dependent variables are the neighbourhood facilities and services. The dependent variables of the neighbourhood facilities and services were facilities for Institution, services for Central Business Districts, services for Infrastructure and Utilities and services for Traffic and Transportation.

The quantitative approach was used to gather the primary data. The questionnaire survey method was used to get the reaction from the residents in the study area. The target respondents were the head of household. In this study, a systematic sampling was used to do the sampling procedure based on 28,649 of total housing in the study area. By using the table for the sample size by Krejcie and Morgan (1970), the suggested sample size of houses for this study area was 379 houses (Chua, 2006). To make easier the number of sampling required are 400 . The study was self-administrated questionnaire survey. The questionnaire will be distributed based on the selected housing sample. The questionnaire was placed in each resident's post box with an addressed prepaid reply envelope to researcher's address. Total final numbers of respondents are 421. The result will be analysed by using two types of analysis. The descriptive analysis to analyse the socio-economic residents' background. The ANOVA one-way test distinguished the different for other socio economic of residents' background.

\section{RESULTS AND DISCUSSION}

\section{Residents' Socioeconomic Profile}

The residents' household profile information was derived from the information in Section A of the questionnaire, which involved the socioeconomic background of the residents. The nominal and ordinal scale data was placed in the formal one-way contingency table for easy reading. In brief, the socioeconomic background of the residents showed the employment, income, housing type, home ownership, and vehicle ownership. The summary of the residents' socioeconomic background is shown in Table 2. The highest percentage of resident employment was 
Vol 3, No 2 (2020): September (Jurnal Arsitektur dan Perencanaan)

professional and officer at $21.1 \%$, followed by educational at $15.7 \%$, and finally, clerical and support staff at $13.1 \%$. About $10 \%$ of the residents' employment is technical assistant or assistant officer and retirees. A minority of below $10 \%$ of the residents are managers, armed force, sales and services, production operator, general workers, housewives, and others. Other employment included those who are self-employed, business men or business women, contactors, and others.

The total income of the residents was between RM 1,000 - RM 3,000 at $39.9 \%$ and between RM 3,001 - RM 5,000 at 30.9\%. The income of more than RM 5,000 was at $18.8 \%$ and the income of RM 1,000 and below was at $10.7 \%$. The majority of the residents live in intermediate cost terrace housing at $52.5 \%$ and quite a number of the residents live in bungalow housing at $18.5 \%$. The remaining residents' lives in low cost housing at $14.0 \%$ and semi-detached housing at $15.0 \%$, respectively. Most of the residents are the owner of their house at $88.6 \%$ and the rest are rentals and either company or government rentals at $11.4 \%$. Largely, the residents have their own vehicle at $99.8 \%$ and only $0.2 \%$ residents do not have any vehicle.

Table.2 Residents' Socio-Economic Backgrounds Residents' Socioeconomic Backgrounds

\begin{tabular}{|c|c|c|}
\hline $\begin{array}{c}\text { Variables } \\
\text { Employment }\end{array}$ & Frequency & Percentage \\
\hline Manager & 37 & 8.8 \\
\hline Professional / Officer & 89 & 21.1 \\
\hline Education & 66 & 15.7 \\
\hline $\begin{array}{l}\text { Technical Assistant / Assistant } \\
\text { Officer }\end{array}$ & 41 & 9.7 \\
\hline Armed Force & 27 & 6.4 \\
\hline Clerical / Support Staff & 55 & 13.1 \\
\hline Sales and Services & 19 & 4.5 \\
\hline Production Operator & 1 & 0.2 \\
\hline General Workers & 25 & 5.9 \\
\hline Retirees & 46 & 10.9 \\
\hline Housewives & 2 & 0.5 \\
\hline Others & 13 & 3.1 \\
\hline Total & 421 & 100.0 \\
\hline RM 1,000 and below & 45 & 10.7 \\
\hline RM1,001 - RM3,000 & 168 & 39.9 \\
\hline RM3,001 - RM5,000 & 130 & 30.9 \\
\hline RM5,001 - RM7,000 & 53 & 12.9 \\
\hline RM7,001 and above & 25 & 5.9 \\
\hline Total & 421 & 100.0 \\
\hline Housing Type & Frequency & Percentage \\
\hline Low Cost Terrace Housing & 59 & 14.0 \\
\hline $\begin{array}{l}\text { Intermediate Cost } \\
\text { Housing }\end{array}$ & 221 & $\mathbf{5 2 . 5}$ \\
\hline Semi-Detached Housing & 63 & 15.0 \\
\hline Bungalow & 78 & 18.5 \\
\hline Total & 421 & 100.0 \\
\hline Home Ownership & Frequency & Percentage \\
\hline Owner & 373 & 88.6 \\
\hline Rental & 41 & 9.7 \\
\hline Government / Company & 7 & 1.7 \\
\hline Total & 421 & 100.0 \\
\hline
\end{tabular}


Vol 3, No 2 (2020): September (Jurnal Arsitektur dan Perencanaan)

\begin{tabular}{|c|c|c|}
\hline Vehicle Ownership & Frequency & Percentage \\
\hline Motorcycle & 15 & 3.6 \\
\hline Car / Van & 110 & 26.1 \\
\hline Bicycle and Motorcycle & 6 & 1.4 \\
\hline Bicycle and Car & $\begin{array}{l}10 \\
59\end{array}$ & 2.4 \\
\hline $\begin{array}{l}\text { Motorcycle and Car } \\
\text { Bicycle, Motorcycle and Car }\end{array}$ & 29 & $\begin{array}{l}14.0 \\
\mathbf{5 2 . 3}\end{array}$ \\
\hline No Vehicle & 1 & 0.2 \\
\hline Total & 42 . & 100 \\
\hline
\end{tabular}

\section{Level of Satisfaction of Neighbourhood Quality in Relation with} Neighbourhood Facilities and Services by Different Monthly Incomes

Monthly incomes will interpret the status of the people. The findings from the socioeconomic background indicate that the monthly income in the study area can be divided into three categories, which are RM 3,000 and below, between RM 3,001-RM 7,000, and above RM 7,000. These categories can be classified as low-income group for category below RM3,000, middle income group for category between RM3,001 to RM7,000 and high-income group for category above RM7,000. In this study, the different monthly incomes will be tested with the ANOVA one-way analysis. The residents who have different monthly incomes will evaluate the facilities and services in their neighbourhood area. From the result in Table 3, the average mean core shows that the level of satisfaction is still below 4.00. The facilities and services provided have still not reached the satisfied standards stipulated by the residents with different monthly incomes.

The findings show that although there are various groups of peoples' living standard, their needs and aspiration of the facilities and services are the same and identical. However, the results of monthly income show all are at the moderate level if refer in detail the result can be ranked to get the highest and lowest satisfaction of neighbourhood facilities and services provided for them. Based on the detail result the highest rank is low income group with $\mathrm{M}=3.63$, second rank is middle income group with $\mathrm{M}=3.55$ and lastly the lowest is high income group. These results show that the residents with different monthly income will express the different satisfaction of the residents of neighbourhood facilities and services provided in their neighbourhood area.

\section{The Level of satisfaction of Neighbourhood Quality in Relation with Neighbourhood Facilities and Services by Different Home Ownership Classes}

Home ownership classes can also interpret the standard of living and income category of the people. The findings from the socioeconomic background indicate that the different home ownership classes can be classified as owner, tenant, and others. In this study, the different home ownership classes will be tested with the ANOVA one-way analysis. The residents who have different home ownership will evaluate the facilities and services in their neighbourhood area. Referring to the result in Table 4 , the average mean score shows that the level of satisfaction is similar with the above findings, which are still below the satisfaction of 4.00. The 
facilities and services provided have not yet achieved the satisfied standards specified by the residents with different home ownership.

The findings show that although there are various groups of living standards, their needs and aspiration of the facilities and services are similar. However, the result of total average can be ranked to get the highest and lowest level of satisfaction of neighbourhood facilities and services provided in their neighbourhood area. By comparing the total average, the highest is rental, second is other and lastly owner house. These results show that the owners of house are more particular with the neighbourhood facilities and services in their neighbourhood area. They wanted more improvement facilities and services in the future development. 
Vol 3, No 2 (2020): September (Jurnal Arsitektur dan Perencanaan)

\section{Table.3 Level of Satisfaction with Different Monthly Incomes}

\begin{tabular}{|c|c|c|c|c|c|c|c|c|c|c|}
\hline \multirow{2}{*}{$\begin{array}{c}\text { Neighbourhood Facilities and Services } \\
\text { Category }\end{array}$} & \multirow{2}{*}{$\begin{array}{c}\text { Neighbourhood Facilities and } \\
\text { Services Item }\end{array}$} & \multicolumn{3}{|c|}{$<$ RM3000 } & \multicolumn{3}{|c|}{ RM3001-7000 } & \multicolumn{3}{|c|}{ >RM7000 } \\
\hline & & $\mathbf{N}$ & $\mathbf{M}$ & SD & $\mathbf{N}$ & $\mathbf{M}$ & SD & $\mathbf{N}$ & $\mathbf{M}$ & SD \\
\hline \multirow[t]{8}{*}{ Public Institution (Facilities) } & Health & 211 & 3.61 & 0.764 & 180 & 3.60 & 0.697 & 24 & 3.63 & 0.576 \\
\hline & Educational & 178 & 3.79 & 0.737 & 158 & 3.79 & 0.640 & 22 & 3.82 & .733 \\
\hline & Police and Security & 181 & 3.74 & 0.769 & 165 & 3.78 & 0.584 & 23 & 3.74 & .449 \\
\hline & Fire and Rescue & 147 & 3.90 & 0.628 & 140 & 3.87 & 0.584 & 19 & 3.58 & 0.692 \\
\hline & Post Office & 212 & 3.56 & 0.845 & 182 & 3.57 & 0.757 & 24 & 3.25 & 0.676 \\
\hline & Worship Place & 212 & 4.10 & 0.779 & 183 & 4.04 & 0.708 & 25 & 4.08 & 0.640 \\
\hline & Cemetery & 162 & 3.76 & 0.864 & 147 & 3.65 & 0.849 & 20 & 3.25 & 0.716 \\
\hline & Average & 213 & 3.80 & 0.669 & 183 & 3.79 & 0.570 & 25 & 3.56 & 0.507 \\
\hline \multirow[t]{4}{*}{ Public Institution (Services) } & Public Library & 190 & 3.37 & 0.953 & 158 & 3.23 & 0.894 & 19 & 3.00 & 0.816 \\
\hline & Public Hall & 79 & 3.50 & 0.837 & 74 & 3.42 & 0.768 & 13 & 3.31 & 0.751 \\
\hline & Open Space and Recreational & 195 & 3.40 & 0.925 & 158 & 3.24 & 0.901 & 19 & 3.00 & 0.816 \\
\hline & Average & 195 & 3.40 & 0.925 & 159 & 3.21 & 0.877 & 19 & 3.05 & .705 \\
\hline \multirow{7}{*}{$\begin{array}{l}\text { Infrastructure and Utilities } \\
\text { (Facilities and Services) }\end{array}$} & Water Supply & 213 & 4.04 & 0.698 & 183 & 3.92 & 0.740 & 25 & 3.84 & 0.850 \\
\hline & Electrical Supply & 213 & 3.91 & 0.807 & 183 & 3.88 & 0.758 & 25 & 3.88 & 0.666 \\
\hline & Telecommunication & 213 & 3.41 & 1.143 & 183 & 3.58 & 0.882 & 25 & 3.56 & 0.712 \\
\hline & Sewerage & 213 & 3.63 & 0.867 & 183 & 3.60 & 0.716 & 25 & 3.20 & 0.816 \\
\hline & Drainage & 213 & 3.37 & 1.018 & 53 & 3.23 & 1.068 & 25 & 3.00 & 0.866 \\
\hline & Solid Waste & 213 & 3.59 & 0.920 & 183 & 3.33 & 1.016 & 25 & 3.28 & 0.792 \\
\hline & Average & 213 & 3.71 & 0.710 & 183 & 3.62 & 0.702 & 25 & 3.60 & 0.707 \\
\hline \multirow{7}{*}{$\begin{array}{l}\text { Central Business District } \\
\text { (Facilities and Services) }\end{array}$} & Commercial Activities & 213 & 3.87 & 0.698 & 183 & 3.94 & 0.626 & 25 & 3.88 & 0.666 \\
\hline & Services Activities & 210 & 3.89 & 0.666 & 182 & 3.93 & 0.615 & 25 & 3.92 & 0.759 \\
\hline & Road & 213 & 3.66 & 0.722 & 183 & 3.72 & 0.738 & 25 & 3.76 & 0.663 \\
\hline & Pedestrian Walkways & 157 & 3.45 & 0.852 & 141 & 3.37 & 0.807 & 17 & 3.35 & 0.786 \\
\hline & Street Lighting & 213 & 3.58 & 0.802 & 183 & 3.61 & 0.725 & 25 & 3.60 & 0.707 \\
\hline & Parking Lot & 213 & 3.44 & 0.841 & 183 & 3.32 & 0.766 & 25 & 3.24 & 0.831 \\
\hline & Average & 213 & 3.85 & 0.681 & 53 & 3.94 & .718 & 25 & 3.92 & 0.640 \\
\hline \multirow{4}{*}{$\begin{array}{l}\text { Public Transportation } \\
\text { (Services) }\end{array}$} & Public Bus & 147 & 3.36 & 0.993 & 114 & 3.11 & 0.853 & 9 & 3.00 & 0.500 \\
\hline & Public Taxi & 82 & 3.29 & 0.893 & 74 & 3.25 & 0.927 & 9 & 3.00 & 0.500 \\
\hline & Average & 150 & 3.38 & 0.933 & 115 & 3.21 & 0.802 & 14 & 3.14 & 0.663 \\
\hline & Total Average & 197 & 3.63 & 0.784 & 139 & 3.55 & 0.734 & 22 & 3.45 & 0.644 \\
\hline
\end{tabular}

Note: $1=$ Strongly Not Satisfied, $2=$ Not Satisfied, $3=$ Moderate, $4=$ Satisfied, $5=$ Strongly Satisfied

$\mathrm{N}=$ Sample, $\mathrm{M}=$ Mean, $\mathrm{SD}=$ Standard Deviation 
Jurnal Arsitektur dan Perencanaan (JUARA)

Hal. 160-172: ISSN Online: 2620-9896

Vol 3, No 2 (2020): September (Jurnal Arsitektur dan Perencanaan)

\begin{tabular}{|c|c|c|c|c|c|c|c|c|c|c|}
\hline \multicolumn{11}{|c|}{ Table.4 Level of satisfaction with Different Home Ownership } \\
\hline \multirow{2}{*}{$\begin{array}{c}\text { Neighbourhood } \\
\text { Facilities and Services } \\
\text { Category }\end{array}$} & \multirow{2}{*}{$\begin{array}{c}\text { Neighbourhood Facilities and } \\
\text { Services Item }\end{array}$} & \multicolumn{3}{|c|}{ Owner } & \multicolumn{3}{|c|}{ Rental } & \multicolumn{3}{|c|}{ Others } \\
\hline & & $\mathbf{N}$ & $\mathbf{M}$ & SD & $\mathbf{N}$ & $\mathbf{M}$ & SD & $\mathbf{N}$ & $\mathbf{M}$ & SD \\
\hline \multirow{8}{*}{$\begin{array}{l}\text { Public Institution } \\
\text { (Facilities) }\end{array}$} & Health & 367 & 3.64 & .717 & 41 & 3.66 & .617 & 7 & 3.71 & .488 \\
\hline & Educational & 322 & 3.81 & .650 & 29 & 3.90 & .772 & 7 & 3.71 & .951 \\
\hline & Police and Security & 324 & 3.78 & .622 & 39 & 3.85 & .779 & 6 & 3.83 & .408 \\
\hline & Fire and Rescue & 268 & 3.90 & .592 & 34 & 3.79 & .729 & 4 & 4.00 & .000 \\
\hline & Post Office & 370 & 3.51 & .794 & 41 & 3.76 & .799 & 7 & 3.57 & .535 \\
\hline & Worship Place & 372 & 4.09 & .708 & 41 & 4.24 & .767 & 7 & 4.00 & .577 \\
\hline & Cemetery & 297 & 3.69 & .801 & 26 & 3.46 & 1.272 & 6 & 3.67 & 1.033 \\
\hline & Average & 373 & 3.78 & .585 & 41 & 3.93 & .608 & 7 & 3.71 & .488 \\
\hline \multirow{4}{*}{$\begin{array}{l}\text { Public Institution } \\
\text { (Services) }\end{array}$} & Public Library & 323 & 3.26 & .906 & 38 & 3.16 & .973 & 6 & 3.50 & .548 \\
\hline & Public Hall & 147 & 3.46 & .752 & 15 & 3.20 & 1.207 & 4 & 3.75 & .500 \\
\hline & Open Space and Recreational & 323 & 3.27 & .907 & 38 & 3.16 & .973 & 6 & 3.50 & .548 \\
\hline & Average & 329 & 3.26 & .883 & 38 & 3.26 & .978 & 6 & 3.50 & .548 \\
\hline \multirow{7}{*}{$\begin{array}{l}\text { Infrastructure and } \\
\text { Utilities } \\
\text { (Facilities and } \\
\text { Services) }\end{array}$} & Water Supply & 373 & 3.95 & .735 & 41 & 4.12 & .600 & 7 & 3.86 & 1.069 \\
\hline & Electrical Supply & 373 & 3.87 & .769 & 41 & 3.98 & .790 & 7 & 4.00 & .816 \\
\hline & Telecommunication & 373 & 3.48 & .960 & 41 & 3.27 & 1.265 & 7 & 4.00 & .816 \\
\hline & Sewerage & 373 & 3.54 & .834 & 41 & 3.66 & .728 & 7 & 3.71 & .488 \\
\hline & Drainage & 373 & 3.21 & 1.028 & 41 & 3.32 & .986 & 7 & 3.14 & .690 \\
\hline & Solid Waste & 373 & 3.42 & .971 & 41 & 3.56 & .838 & 7 & 3.00 & .577 \\
\hline & Average & 373 & 3.62 & .687 & 41 & 3.73 & .633 & 7 & 3.86 & .378 \\
\hline \multirow{7}{*}{$\begin{array}{l}\text { Central Business } \\
\text { District } \\
\text { (Facilities and } \\
\text { Services) }\end{array}$} & Commercial Activities & 373 & 3.92 & .610 & 41 & 3.90 & .664 & 7 & 3.86 & 1.069 \\
\hline & Services Activities & 371 & 3.91 & .605 & 39 & 3.97 & .628 & 7 & 3.86 & 1.069 \\
\hline & Road & 373 & 3.73 & .700 & 41 & 3.71 & .680 & 7 & 3.43 & .787 \\
\hline & Pedestrian Walkways & 276 & 3.42 & .807 & 35 & 3.46 & .817 & 4 & 3.50 & 1.000 \\
\hline & Street Lighting & 373 & 3.58 & .728 & 41 & 3.73 & .633 & 7 & 3.71 & .756 \\
\hline & Parking Lot & 373 & 3.38 & .793 & 41 & 3.51 & .597 & 7 & 3.14 & .690 \\
\hline & Average & 373 & 3.65 & .642 & 41 & 3.68 & .650 & 7 & 3.71 & .488 \\
\hline \multirow{4}{*}{$\begin{array}{l}\text { Public Transportation } \\
\text { (Services) }\end{array}$} & Public Bus & 240 & 3.30 & .898 & 33 & 3.18 & .917 & 2 & 3.00 & .000 \\
\hline & Public Taxi & 142 & 3.25 & .879 & 23 & 3.22 & .902 & 0 & 0 & 0 \\
\hline & Average & 244 & 3.32 & .839 & 33 & 3.27 & .876 & 2 & 3.00 & .000 \\
\hline & Total Average & 338 & 3.53 & 0.727 & 39 & $\mathbf{3 . 5 7}$ & 0.749 & 6 & 3.56 & 0.380 \\
\hline
\end{tabular}

Note: $\quad 1=$ Strongly Not Satisfied, $2=$ Not Satisfied, $3=$ Moderate, $4=$ Satisfied, $5=$ Strongly Satisfied $\mathrm{N}=$ Sample, $\mathrm{M}=$ Mean, $\mathrm{SD}=$ Standard Deviation 


\section{CONCLUSION}

The level of satisfaction evaluation has been frequently used for numerous other arenas of study. In any study the socio-economic preferences are very significant variable must be encompassed. This study has been used the different of socio-economic background to assess the neighbourhood facilities and services. The socio economic used were monthly income and home ownership. The findings have shown of two elements of socio economic are below level of satisfaction with Mean below 4.00 level of satisfaction of neighbourhood facilities and services. Even though the overall results are below satisfaction but the detail result can be ranked to get to know the highest and lowest satisfaction of neighbourhood facilities and services. For different monthly income the result shows that the lower income people has less moderate level of satisfaction (3.63) then higher monthly income (3.45). Nevertheless, peoples who have different home ownership gives almost similar result with average moderate below 4.00 scale. People who stay at their own house scale at 3.53, who stay at rental house scale at 3.57 and another house scale ate 3.57. Based on the result the local authority the Manjung Municipal Council and related agencies must be taking into account to upgrade and improve the neighbourhood facilities and services in their neighbourhood area. The feedbacks from the peoples are the best method to get the actual situation and exact facts.

\section{REFERENCES}

Aiello, A., Ardone, R. G., \& Scopelliti, M. (2010). Neighbourhood Planning Improvement: Physical Attributes, Cognitive and Affective Evaluation and Activities in Two Neighbourhoods in Rome. Evaluation and Program Planning, (33), 264-275.

Bonaiuto, M., Fornara, F., \& Bonnes, M. (2003). Indexes of Perceived Residential Environment Quality and Neighbourhood Attachment in Urban Environments: A Confirmation Study on the City Of Rome. Landscape and Urban Planning(65), 41-52.

Chau, C. K., Yung, H. K., Leung, T. M., \& Law, M. Y. (2006). Evaluation of Relative Importance of Environmental Issues Associated With a Residential Estate in Hong Kong. Landscape and Urban Planning, (77), 67-79.

Chua, Y. P. (2006). Kaedah dan Statistik Penyelidikan Kaedah Penyelidikan (Vol. 1). Malaysia: Mc-Graw Hill (Malaysia) Sdn. Bhd.

Connerly, C. E., \& Marans, R. W. (1985). Comparing Two Global Measures of Perceived Neighborhood Quality. Social Indicators Research, 17, 29-47.

Djebarni, R., \& Al-Abed, A. (2000). Satisfaction Level with Neighbourhoods in Low-Income Public Housing in Yemen. Property Management, 18(4), 230242.

Erkip, F. (2010). Community and Neighborhood Relations in Ankara: An UrbanSuburban Contrast. Cities, (27), 96-102.

Fornara, F., Bonaiuto, M., \& Bonnes, M. (2010). Cross-Validation of Abbreviated Perceived Residential Environment Quality (PREQ) and Neighborhood Attachment (NA) Indicators. Environment and Behavior, 42(2), 171-196. 
Galster, G. C., \& Hesser, G. W. (1981). Residential Satisfaction: Compositional and Contextual Correlates. Environment and Behavior, 13(6), 735-758.

Gbakeji, J. O., \& Magnus, O. O. (2007). Aspects of Residential and Neighbourhood Preferences in the Warri Metropolis, Delta State, Nigeria. Studies Home Communication Science, 1(12), 121-126.

Ge, J., \& Hokao, K. (2004). Residential Environment Index System and Evaluation Model Established by Subjective and Objective Methods. Journal Of Zhejiang University Science, 5(9), 1028-1034.

Ge, J., \& Hokao, K. (2006). Research on Residential Lifestyles in Japanese Cities from the Viewpoints of Residential Preference, Residential Choice and Residential Satisfaction. Landscape and Urban Planning, (78), 165-178.

Lee, T., \& Marans, R. W. (1980). Objective and Subjective Indicators: Effects of Scale Discordance on Interrelationships. Social Indicators Research, 8, 4764.

Manjung Municipal Council. (1997a). Draf Rancangan Tempatan Lumut - Seri Manjung 1997-2010 [Draft Local Plan of Lumut - Seri Manjung 1997 - 2010]. Ipoh: Department of Town and Country Planning Perak State.

Manjung Municipal Council. (1997b). Draf Rancangan Tempatan Lumut - Seri Manjung 1997-2010 [Draft Local Plan of Lumut - Seri Manjung 1997 - 2010]. Ipoh: Department of Town and Country Planning Perak State.

Manjung Municipal Council. (2011). Rancangan Tempatan Daerah Manjung (Pengubahan) 2020 [Manjung Distrcit Local Plan (Alteration) 2020]. Ipoh: Departmant of Town and Country Planning Perak State.

Niezabitowski, A. (1987). Study of Residential Environment and Psychological Needs. Design Studies, 8(2), 109-116.

Ogu, V. I. (2002). Urban Residential Satisfaction and the Planning Implications in a Developing World Context: The Example of Benin City, Nigeria. International Planning Studies, 7(1), 37-53.

Sirgy, M. J., \& Cornwell, T. (2002). How Neighborhood Features Affect Quality of Life. Social Indicators Research, 59, 79-114.

Sulaiman, H., \& Yahaya, N. (1987). Housing Provision and Satisfaction of LowIncome Households in Kuala Lumpur. Habitat International, 11(4), 27-38.

Tan, T. H. (2012). Housing Satisfaction in Medium- and High-Cost Housing: The case of Greater Kuala Lumpur, Malaysia. Habitat International, 36, 108116.

Westaway, M. S. (2006). A Longitudinal Investigation of Satisfaction with Personal and Environmental Quality Of Life in an Informal South African Housing Settlement, Doornkop, Soweto. Habitat International, (30), 175-189.

Yang, M. J., Yang, M. S., Shih, C. H., \& See, I. K. (2002). Development and Validation of an Instrument to Measure Perceived Neighbourhood Quality in Taiwan. Journal of Epidemiology and Community Health, 56(7), 492-496.

Yi, C. C. (1985). Urban Housing Satisfaction in a Transitional Society: A Case Study in Taichung, Taiwan. Urban Studies, 22, 1-12.

Zhao, K. (2009). The Relationships between Perceived Residential Environment Quality and Perceived Restoration in Urban Residents. Paper presented at 
Jurnal Arsitektur dan Perencanaan (JUARA)

Hal. 160-172: ISSN Online: 2620-9896

Vol 3, No 2 (2020): September (Jurnal Arsitektur dan Perencanaan) the 1st International Conference on Information Science and Engineering (ICISE2009). 